\title{
FUNCTIONAL LITERACY AND TEXT CREATION
}

\author{
Dusanka Popovic \\ University of Montenegro - Faculty of Philosophy, Niksic \\ dusana@t-com.me
}

\begin{abstract}
The results of research about functional literacy (i.e. ability to read, understand and create text and understand its further use), and especially those results that 15-year-olds show in Programme for International Student Assessment (PISA), as well as the importance of this competence for life and work in a modern society, indicate the need for analysis of all the segments that affect its development and improvement. Project How to help students to successfully create oral and written, artistic and non-artistic texts addresses this area in particular. The culture of oral and written expression, as productive language skills, is very interesting to research, and especially to improve. Inseparable from the receptive skills of listening and reading, they are their explicit product. A significant number of theorists and methodologists dealt with this area, but their activity was usually focused on what the teacher needed to do for the students to write well (focused on the process, method, or the result: students' written work). What is unquestionably lacking, but is in the spirit of the changes that we have introduced in our educational system, is dealing with the student as a creator of the text. The observations of methodologists of language and literature teaching prove that this factor in teacher-student-written work conjunction was least dealt with. They point out that the main characteristic of the current literature on the written expression is exaggerated orientation towards written works and neglecting of their authors (creators). The aim of the project was to investigate and recommend the best ways in which to build a functional literacy in the area of successful creation of oral and written text, i.e. to propose a more efficient teaching in the field of oral and written expression. This paper analyzes the opportunities for the development of these areas, providing current educational programs for Mother tongue language and literature in Montenegro, and presents the methodical approach The Creator's path designed as a means of support for all students when creation of text is in question.
\end{abstract}

Key words: functional literacy, text creation, oral and written expression, efficient teaching.

\section{Introduction}

In modern society, literacy is a basic requirement for life, work and progress. Literacy makes us safer, able to be active citizens and critically observe the reality. Only functionally literate individual can be critical when accepting different types of texts he meets daily in a variety of media, and protect himself from negative media messages. Functionally illiterate person is easily manipulated, and, unfortunately, literacy can be seen as a tool of power and oppression that legitimizes opinion, the rights and laws of the dominant group, i.e. as a means to create an opinion. Numerous declarations on Human Rights emphasize that literacy is a basic human right, implicit in the right to education; that it does not end in itself and as such, in a broader sense includes the knowledge and skills we all need in this world of rapid change (Universal Declaration of Human Rights, 1948, The Declaration of Persepolis, 1975, Hamburg Declaration, 1997).

In history, understanding of literacy has significantly changed, as well as the role of literacy in the lives of individuals. in the beginning, literacy was defined as mastering the skills of reading and writing letters and words, i.e. skills of decoding. Later it was defined as a person's ability to read with understanding and write a short, simple text on everyday life (UNESCO, 1951). in sixties and seventies a literate person is someone who has acquired the basic knowledge and skills that allow him to fully participate in all activities, which for efficient functioning in group and in society require literacy and achievements in reading, writing and arithmetics allow him to use these skills in order to engage in self development and development of community.

In modern circumstances, literacy is understood as a set of knowledge, skills and strategies which individuals build in life through interaction with their peers and the wider community. Cognitively based theories of reading literacy emphasize the interactive nature of reading and the constructive nature of understanding in printed media (Binkley \& Lynnakyla 1997; Bruner, 1990, Dole, Duffy, Roehler \& Pearson, 1991) and to an even greater extent in the electronic media (Fastrez 2001, Legros \& Crinone, 2002, Leu 2007; Reinking, 1994). The reader generates meaning as a response to text using prior knowledge and level of text and situations that are often socially and culturally conditioned. 
The PISA project developed the following definition of reading literacy: understanding, using, and reflecting on written texts, in order to achieve one's goals, to develop one's knowledge and potential, and to participate in society. (Kirsh et al, 2002; OECD, 2010). This definition of literacy makes it obvious that the reading is not viewed as a unitary skill; rather, it is part of the process, approaches and skills that vary depending on the reader, text type, as well as on the aim or a situation in which the reading happens (Campbell et al, 2001).

Cognitive understandings that emphasize the interactive nature of the reading process and constructivist, creative nature of the process of understanding, are the concept of Reading Literacy on which the PISA project is based. The meaning of the text is constructed in reader-text interaction, and what the reader brings in that interaction are the cognitive and metacognitive strategies of text processing. Also important are the previous knowledge and experience gained in reading situations (eg, use of textual and situational incentives). Text contains certain linguistic and structural elements, and refers to a particular topic, while the context conditions the aim of reading and, through this aim, the processes of reading that are appropriate both for the aim and the text.

Professional literature (domestic and foreign) states several types of functional literacy, depending on the perspective taken, i.e. what is taken as a basis of classification: literacy of school youngsters and adult literacy, reading literacy, lexical literacy, media literacy, computer literacy, science, research, IT literacy and so on.

Literacy in the modern society is a process; the preservation and development of literacy lasts through a lifetime - social changes always bring new and different demands for literacy. The level and quality of one's literacy are affected by innate and acquired abilities, different skills s/he owns, environment, way of acquiring and developing these skills through the educational system, the level of economic, technological and cultural development of society and the like.

It is known that, after the children acquire basic literacy, the first condition of preserving and improving their own literacy is to continually read - develop and improve reading skills. Development of reading skills is not a task for only the initial teaching of reading, but a skill that requires special effort and investment by both teachers and students throughout the schooling. Reading becomes demanding, with subject that is constantly expanding and becoming more diverse and more complex - as students get older: reading of various literary and artistic texts, reading non-artistic texts for different purposes, informative reading in different situations, reading for personal pleasure, interpretative and expressive reading, learning by reading - reading as a lifestyle, as one of the most complex forms of human social behavior (Grossman, 2010). and of course, after reading - comes the writing, as a productive skill, as a need and as creativity.

Researchers in this field around the world are dealing with the process of reading: starting with the recognition of characters and their organization into words, word sequences into sentences, the problems that occur in these phases, ending with the different ways of studying and interpreting the text. Modern societies around the world, at least nominally, are showing interest in improving the literacy, i.e. care for the poor results in national and international tests literacy. Alarmingly, the interest in reading is declining, the majority of school age children are more interested in other kinds of fun - moreover, they asses reading, and especially home reading, as an additional burden, etc. in most European countries there are national bodies to coordinate and support activities that promote reading, developing specific strategies to improve these skills (EACEA P9 Eurydice, 2011). The downfall of functional literacy in a country is for a concern. That is why this area calls for educational reforms, and changes in curricula that define the instruction process in schools.

Research on literacy in the region and in Montenegro - National and international surveys of students' reading literacy in the region and in Montenegro indicate that intensive work needs to be done on the development of these skills, changing many of the steps and approaches in the process of teaching and learning.

The first study (Educational achievements of eighth-grade students from five elementary schools in Montenegro, 2001) measuring the reading speed and reading comprehension, noted that the eighth-grade students showed unsatisfactory level of general and basic literacy. This means that students were leaving the elementary school not having the sufficient knowledge and skills to enable them to be productively involved in various areas of secondary education, to understand different everyday situations and be literate in acting in such situations (Havelka et al., 2001).

Another study: Republic testing of educational achievements of third-grade primary school students in the Mother tongue and Mathematics (2006) (Durković, N. et al., 2006) in which the understanding of the text was checked, rather than the technique of reading itself, showed that the students of this age were the poorest in reading.

In 2006 Montenegro joined 56 other countries in the Programme for International Student Assessment (PISA). Results of PISA 2006 in Montenegro indicate that more than half of tested 15-year-olds (56.3\%) were not trained in critical reading and understanding texts (artistic and non-artistic), and that they have difficulties to apply given information in new situations. PISA 2009 results were hardly better, showing that $49.5 \%$ of our students is below level 2 (minimal level of functional 
literacy, i.e. the lower limit of functional literacy in the domain of reading literacy), but this in turn means that about $50 \%$ of our 15-year-olds are functionally illiterate (National Report, 2008; Jacimovic, 2009). in 2012 testing we were 53rd among 65 countries. in the final sum this means that we advanced one place in reading as compared to 2009. With regard to the actual number of points (422), the difference compared to the average score of the OECD countries (496) is still high. in 2012 the percentage of functionally illiterate students (below level 2) is still significantly higher than in the OECD countries.

Analyses of some segments of the Montenegrin education system show that there is a ground for improvement of functional, and with it - reading literacy. This ground is, amongst other, provided by teaching-and-goal-oriented curricula for Mother tongue and literature, which within the objectives and contents allow enough space to work on the artistic and non-artistic texts, i.e. to develop reading strategies for both text types, as well as an understanding of the two uses of language (artistic and non-artistic). They allow also a balanced development of 4 language components: listening, speaking, reading and writing.

Functional literacy involves the creation of diverse texts, as an important field of teaching oral and written expression. Students should be trained to write meaningful, comprehensive and purposeful text, nevermind artistic or non-artistic. Therefore, the ways to introduce students into this skill and the ways to develop it further through education were considered. The application of teaching method The Creator's path in 13 primary schools showed that all students can create a solid text - if the teacher leads them skillfully.

\section{Why The Creator's path?}

Creating texts of various kinds has been a regular part of the Mother tongue and literature curricula, and it is realized within language teaching and literature teaching. Namely, the students create artistic and non-artistic texts modeled on the texts they read and in accordance with their capacities. The intention of creating this teaching method is to try to transfuse previous theoretical assumptions and practical experiences into a concrete method so that, when it comes to text creation, teachers can provide adequate and continuous support to their students from the first grade to the end of elementary school. The objective of this effort is not to create writers, but to enable each individual to develop, within his capacities, writing ability during elementary school, so that these knowledge and skills would help him be a competent citizen, both within his profession, and in regular life situations.

The idea presented here is not entirely new. But the way of its application in teaching students to create text is new. These issues are mainly dealt with the theory of literacy, which is, taken in a narrower sense, interested only in specific issues related to those forms of written expression in which all the compositional elements of written text are represented. Preparational forms for text production (dictation, transcription, lexical exercises, retelling), which also have their own importance and its theoretical development, are much more treated in the current methods of written expression teaching, and that is why they are felt closer and more familiar. Teaching methods, as a discipline, is much closer to the teaching practice, and therefore it monitors all stages of the development of pupils' literacy. Limited only to the compositional forms of written expression, theory of literacy is mainly engaged in: the selection and validity of the topics for writing, collecting and selecting material for the topic, its development (composing), forms of expression, shaping paragraphs and sentences, the adequacy of words and phrases, the general appearance of the written paper and the like.

By presenting theoretical assumptions and illustrating theory with examples from practice, Dimitrijevic, in his book Theory of Literacy Basics (1969), specified the path that teachers could lead students in creating a quality text. in the chapter on composition and style of written paper, in his book Theory of Literature with the Theory of Literacy (2001), Zivkovic through the basic assumptions of the theory of literacy shapes a similar way in creating a good text. Stevanovic, too, in his book Theory and Practice in Teaching Oral and Written Expression (1988), dealing more with practice and specific teaching instructions, provides guidelines for successful learning and teaching in this field. This approach is actualized in the last two decades to support the introduction of process-oriented approach to teaching, and can be found in many textbooks of American, English and, in general, Western European production.1 The goal here was to analyze it through the practical application in classroom, and to amend it, perhaps correct it and than show how useful and beneficial it is primarily for

1 Dimitrijević, R. (1969): Osnovi teorije pismenosti, prerađeno i dopunjeno izdanje, „Vuk Karadžić“, Beograd; Živković, Stevanović, M. (1988): Teorija i praksa u nastavi usmenog i pismenog izražavanja, „Dječje novine“, Gornji Milanovac; Burke Walsh, K. (1996): Creating child-centered classrooms, 6-7 Year Olds, Step By Step: A Program for Children and Families. Children's Resources International, Inc., Washington, DC.; Open Society Inst., New York, NY; Burke Walsh, K. (1997): Creating child-centerd classrooms, 8-10 Year Olds, A Program for Children and Families Children's Resources International, Inc., Washington, DC; Open Society Inst., New York, NY; Živković, D. (2001): Teorija književnosti sa teorijom pismenosti, Draganić, Beograd; Booth, D. \& Swartz, L. (2004): Literacy Techniques, Ontario, Canada: Pembroke Publishers Limited. 
students. Then, insisting on the process, not the time, check out when and how its implementation can be organized and planned (number of hours, which forms of teaching, for how long, etc). and finally, make it a part of the everyday life of both, the teachers and the students.

Types of texts that students create and the forms of expression - According to the basic requirements of the theme, its focus and the attitude towards it, the body of the text can be elaborated in various shapes. That is why there are different types and forms of student composition, and methodologists state the following: narrative (of events - indirectly and directly - experience), descriptions, reporting, informative, business papers, debates, excerps, presentations... Which form of composition the teacher will choose, depends on the age of the students and is usually prescribed in the curriculum for a particular grade.

Principles of composing/textuality - It is very important that text creation is taught by teachers who know and understand the principles of composition, i.e. the principles of textuality. These principles should not be specified, nor explained to students. The teacher should strive to make students recognize the principles and understand them in the texts of others, exemplary texts, and to spontaneously apply them in the texts they create. in the theory of literacy the following principles of composition/textuality are formulated: the principle of text unity, the principle of details selection, the principle of harmony and coherence, the proportion principle, the principle of expressiveness or emfaza and the principle of diversity.

The principle of text unity refers to the unity of purpose (adherence to the main idea in writing the text, which is achieved by limiting the topic with the title and setting point of view), the unity of thought (all the details and ideas in the text should be firmly and unambiguously associated with the main thought/idea), unity of presentation (ideas or details that the student brings in the text should be strongly related to the topic) and the unity of tone and feeling, i.e. style adequacy (the unity of content and form).

The principle of ideas/details selection involves the accurate determination of the goal, theme framing and its precise formulation, as well as keeping track of the time that is available to work on a specific topic. The choice of details depends on the writer (in this case student), the purpose of the text and the expectations of the audience for which it is writen.

The principle of harmony and coherence means arranging selected details in a logical and natural order - the correlation should exist not only between the threme and details but also between the details. Ideas are classified into groups according to their mutual similarity, or connection, and so they form paragraphs. The paragraphs are interconnected in a natural logical sequence as are the sentences. When the text is read, it should be clear why a particular paragraph preceds the one that is being read, why a thought in this paragraph is preceded by another and so on. There are mainly four types of associations or relationships between ideas, information and facts, e.g. images: time ratio, the space ratio, the ratio of analogies/similarities and cause-and-effect ratio.

The principle of proportion is also the natural law of expressing a certain matter. According to this principle, every detail in a written text should be given as much space as it needs in order of importance to the whole, to the point of view, to the current situation and the circumstances. The principle of proportion applies to the text as a whole, but also its parts: paragraph and sentence. in any case, the writer should give the main idea in the text the most of space, as well as to the main idea in a paragraph.

The principle of expressiveness or emfaza dictates the most important details to receive the most important place in the text, paragraph or sentence. It is known that such places are the beginning and end of the text. Since the introduction is very important, meticulously addressing the topic, thinking about its quintessence and objective to be achieved by correctly and clearly structured point of view, provides good introductions, e.g. emphatic, expressive and strong beginnings.

The principle of diversity provides a reader's attention, refreshes it, and makes it constantly awake and receptive to new impressions and knowledges that are presented in the written composition. Monotony can be caused by uniformity of paragraphs and sentences, use of same words and the scarcity of ideas, thoughts and expressions.

The individualization of the writing process on which this procedure is based was quite a difficult step for teachers accustomed to the collective approach to the activities of the school. Monitoring of teaching and interviews with teachers relating to the use of this teaching method, clearly show that guidelines for the text are still imposed to students, so that the procedure itself is no more the authentic way of the creator. If we agree on a common theme, that's fine, but most teachers are still giving the choice of voting common title for the entire class. Instead, it should be a great opportunity for students to select depending on their own desires and interests. When the agreed theme is for example: Autumn morning, isn't the aim for students to individually choose a point of view and also write about things with which they certainly have a personal, direct or indirect experience? Isn't it a restricting for some of them if it is voted a joint title to be: Autumn morning in my street, when some of them would just like to write about their experience with autumn morning in the garden, in a meadow, 
in the woods, in the park...? This was clearly seen when using the brainstorming technique they listed the possible headlines about the given theme.

What also continues is the practice of developing a common work plan, which is not the aim of this activity. Development of a common plan is a way of exercise on how to make a plan, but the goal of this approach is that students do it themselves, in accordance with their capacities, while the teacher is there to just to help. However, since this is a fairly major change in the approach to teaching writing, such reactions are understandable.

Participants in the project, along with the professional team, answered the question Why Creator's path with following statements: learning, practicing the text creation; process through which students are led by a teacher - he teaches them; process which results show that everyone can write a text under certain circumstances (with appropriate support, respecting the individual needs...); process that motivates and builds confidence; a process that allows students to gain a certain routine and be faster when they need to: a) write the text for one hour (written exercise, a written assignment), b) write the text in the limited time for the exam: external-internal examination, external testing, external graduation exam...

\section{Teaching Method The Creator's path or how to create text}

Creative act consists of the following stages: (1) Choose a theme and set the title, (2) Collect and select materials for the text, (3) Make a text plan, (4) Write the first draft (5) Consult friends and teachers/educators, (6) Improve your text - write another version, (7) Check your spelling, correct errors, (8) Carefully rewrite or retype the text, (9) If you want - publish your article / book and present it to readers.

Choose a theme and set the title - Topics for texts can be taken from experience, i.e. related to what the student saw and learned through observation, direct way. It should, however, be careful when choosing such topics as it may turn out that, in fact, they relate to something that is acquired by a long life experience and not at all easy for students. Typical example of such a theme, regardless of whether it relates to the character from what is read: Age is wisdom.

Topics can be drawn from what the student learns, reads or has read - indirectly learned (from reading materials, from other subjects, from newspapers, from literary journals and magazines for young people). Also, they may come out of the student's imagination. Such themes present a creative independent work of students (often require special skills: live productive imagination, the ability of a strong imagination and innovative skills in combining the details, in conjunction with the form of text, and in particular in the style and language).

Theme that answers its purpose (students speak or write about it) must be specific, which means clear, precise and strictly limited in its formulation.

Ambiguous themes should be avoided because they confuse students. These are, for example: Our school, Life in the city, Rain, Vanjka (Anton Pavlovich Chekhov)... How specific can a student be when writing about so generaly and abstractly set topics? What's specific information, specific request in these topics? What kind of a response we expect? What kind of stylistic forming of ideas and feelings, what kind of clarity?

Difficulties will immediately disappear if the topic is narrowed, limited to something completely certain and known, reduced to the material that the student is familiar with, that is in his experience. The theme Summer holidays, for example, is much more specific if the title specifies what should be discussed within this period, i.e. if the title is formulated as: My holidays in the mountains. However, if we take into account that not all students were in the mountains that summer, we create space for a specific title by leaving the possibility for students to complete the formulation ... at sea, ... in the country... Any theme that is concretized through the title receives a student's personal touch.

As already stated, concrete formulation of a theme/topic is a headline / title. There may be several titles for a theme. Preferably, the possible titles are suggested by students on the basis of discussions about the topic. The title should immediately give the impression of clarity and precision. in fact, the title is the name for what will be written, and should be accurate label of the subject and its concise content, the image of a problem on which the composition is being written. in general, the topic title emerges as soon as a writer is interested in a problem, but its definite formulation is obtained when the material is collected, selected, studied and chosen. The title should be short, convenient and attractive.

Theme should be analyzed; attitudes determined towards the questions that it raises and a personal statement (point of view) formed. Each theme includes three elements: (1) subject (matter): its scope is conditioned by our knowledge, experience, feelings, interests, our whole being and our inner life; (2) point of view/focus of the theme (the opinion that limits the subject, or our viewpoint of the subject); (3) the dominant form of expression (in which the subject shall be presented). 
The point of view involves the attitude towards the issue set in the subject, a way of looking at that issue, so that the reflections and conclusions about the issue set in that way will vary. Point of view (focus of the theme or standpoint) further specifies the subject, guides the work in only one direction, and does not allow roaming and failures in answering the theme. Themes, for which students create texts, or rather learn to create them, should always be formulated so that from the theme title one can clearly identify the subject matter and its point of view / focus of the theme.

Dominant form of expression in the text depends on the theme nature (its internal organic substance), on the matter limited by the point of view, plan adopted by the writer (his concept of developing the theme) and the audience for which it is written.

Theme: The look of forest one summer morning Subject: A friendly gesture

Subject: Forest Subject: Gesture

Viewpoint: A summer morning Viewpoint: Friendly, Friendship, and Companionship

Form of expression: description Form of expression: story/narrative

It is understood that the teacher, relating to the goal of teaching which he set by chosing the theme and formulating it, will often suggest to students the dominant form of expression appropriate to the theme. Form of expression is sometimes explicitly indicated by a certain formula, as: describe, tell a story about, paint a ... write a letter ... design a conversation, etc.).

Analysis of the theme is an essential work to be carried out together with students at the stage of exercise, and over a longer period of working with them, even over several years, until we're confident that students are equiped with skill to perform the required analysis alone.

No theme tcan be written well about, unless student: is well prepared for the act of writing, thought about the subject on which to write, examined all possibilities and suggestions provided about the subject, documented and collected materials, is determined towards materials available in conjunction with the primary objective he set by opting for one or another theme title. Such preparation requires a certain time period, so if a student is surprised by the subject success can't be expected.

Real writers write about topics they choose - free topic choice always gives the best results. The same stands for students. Students, especially younger school-age children, show the best when writing on topics related to direct experience. Issues that "writers" can think about when choosing topics are: What about I keep thinking? What I know a lot about? What I like to do? What is important to me? Who or what I really care about? Which moment was important in my life? What's to worry about? What makes me happy? What makes me angry?

How to make a list of topics and their titles? The teacher, in accordance with the objectives of the program, makes a list of topics and presents it to students (the list can be placed on the wall, and the students can broaden it with new themes and topics that they themselves have formulated and are of an interest to them). Another option is for students to create their own list of topics and keep it in their writing folder. From that list, during the year, they can choose themes and create titles. They can come up with the title of their text through the method that we have already mentioned - brainstorming. Specifically, students are offered a broader topic related to their immediate and shared experience, and then they are asked to write down as many titles related to that topic. After that, the students choose one of the suggested titles for their text.

Collect and select materials for the text. - Collecting materials for the text is the second phase of work and comes after the theme analysis. Materials can be collected indirectly (by finding, discovering material with other people's data, based on others' narratives, based on the book, scientific and artistic works, etc.). and directly (direct observation and observation of the elements required by the senses, through imagination, evoking memories and creating new units based on them). When selecting materials it should be kept in mind to select only the necessary and important details, the ones that are clearly identified by a point of view as a theme limitation. Cumulation of material, so-called documentation is a fundamental activity in the creation of the text: it provides material for the text.

Theme for which we collect material directly (observation)

Theme: Sea at sunset

Subject: Sea 
Viewpoint: Sunset

Form of expression: description

Theme for which we collect material indirectly (reading a book):

Theme: Harry Potter meets Hagrid

Subject: Harry Potter

Viewpoint: encounter with Hagrid

Form of expression: retelling.

Students will learn to select details properly: if they know the aim; if given an unambiguous theme; if they know the time they have available to work on a particular subject / title of the topic; if they know why the text is written, i.e. a situation in which such text needs to be manifested; if they know the audience for which the text is written and its expectations.

Collecting materials, selection of details and their reduction is determined by two principles of textuality: the principle of harmony and coherence and the principle of proportion. These two principles lead to the formation of the correct plan that creates conditions for student to write a meaningful text. Students should be used to analyzing the texts to recognize the application of this principle and to seek arguments to justify such an order in the text, but also to seek and perceive faults in the order of ideas in their own writings. To comply with the previously described principle of proportion, one should practice planning the composition and demarcation of ideas by their relative value and importance, and think about the time, place and space they should be given.

Make a text plan. - The resistance of students to this stage is known, and they often make the plan after they ve done the writing only to suit the forms. Students refuse to make a plan because it demands a particularly difficult mental effort, with a focus and a self discipline, which they at the time of their studies usually do not have, and that should be developed by good teaching.

Here are two important arguments for making a text plan: making a plan is a basic requirement for the development of good literacy; it stimulates the thinking process, properly setting up and developing ideas and identifying their mutual arrangement and subordination, i.e. their relationship. in fact, teaching to plan means: learning logical thinking, getting students used to detect the core of a question, to define their attitudes towards that core, immediately organize the material according to the value and importance related to arrangement and subordination, and to clearly indicate the stages of development of the main idea and those side-by ideas through which the core of the question is exhausted.

Teaching students the planning of oral and written texts teaches them to think about problems, to collect material in response to them and seek, and find, the best way to arrange that material as a response to a question.

Working on that, the student improves many skills. for example, the ability of careful observation and noticing the details in the immediate environment: the students should be used to monitor, investigate and perceive life, its phenomena, nature and the man in it, and to self-observe and self-examine. It also improves the ability of observation and marking of indirect character.

Teachers often choose the easier way and skip or ignore this phase of work on the text creation. When assessing the text it is easier to correct only the formal errors than its conception and development of each individual task. It is much easier to stop on spelling or punctuation errors in the text, and explain and correct them, but to correct students in such complex issues as the overall structure of the text and its logical connectivity.

The consequences of the lack of a plan or a lack of work on text planning are usually: incomplete texts, giving come-first impressions on the title without giving substance and the bad layout of the collected material, causing digressions and a bad style in general.

Practicing in the preparation of the plan begins with exercise of developing a plan of other people's text in the earliest school days. During such exercises the students in other people's texts observe sequence of ideas, their mutual arrangements and subordination, identify the main idea and its development through minor details, observe three basic stages in the development of the main idea: the introduction, development and conclusion and, finally, uncover the core of the issues within the topic. This exercise is carried out within the overall teaching of language and literature.

Text planning can begin only when all the preceding operations that make it meaningful are properly performed, i.e. when: topic is precisely formulated and its analysis carried out, the title is set, the material determined by a point of view, the material collected and organized in accordance with the principles of composition. 
During this method procedure it is possible to create a general and a detailed plan. The general plan may be common for all students, while a detailed plan each student creates for his text. It is the student's individual approach: it manifests student's attitude toward material found and his grasp of issues, his view. Common plan students can make for retelling.

Write the first draft - Students write first drafts in accordance with the preparation. Preferably, the first version is written in class.

Consult friends and teachers/educators - "Writers" should meet with the teacher or peers to discuss the first draft of their texts. Consultations are useful part of the text creation process as "writers" realize that they are writing for an audience. The aim of the consultation is to help the student respond to his writing and to be able to detect and recognize mistakes and correct them. The teacher, through conversation, points to gaps and faults in the composition and content of the story (superfluous characters, random events, descriptions, and dialogues), moving away from the point of view, the introduction of insignificant detail or less important data, poor separation of paragraphs, regular or irregular arrangement of details/data depending on the form of expression, etc. Note that the "writer" should not be criticized, but given specific guidelines for correction and further work on text.

During the consultations, "the writer" should be given the opportunity to read the work in front of a small number of listeners, to hear his own text and the reactions of the group. During the consultation with the teacher student should be the one who speaks the most. Students should be explained that this is an important step in the making of the text, since on the basis of suggestions, questions and complaints they have received, they can make a story more substantial and interesting to readers. They should be given enough time to think about it, to acknowledge the suggestions they recognized as meaningful and useful, and then to write.

This kind of cooperation helps students to easily accept criticism, because they feel secure in an environment that accepts them and that helps them with their questions and comments. "Writers" are not obliged to accept all the suggestions, but they need to record and consider them, and then decide how to use the advice they've been given. Such discussions help students visualize not only from the perspective of a writer, but also from the perspective of critical and constructive-minded reader and listener that provides support to other writers.

In addition to the opportunity to improve literacy, this kind of work, which includes learning and creation within group, contributes to rising to a higher level of the interconnectedness of language components: reading - listening - writing.

Improve your text - write another version - Students, in accordance with the suggestions received, correct their texts. Changes may relate to the content relevance with respect to the subject matter and point of view, the characters and their roles in the story, the events and their order, etc; the adjustment of style to narration form, improving the description, the introduction of new details, etc. Teacher checks whether the corrections are done correctly and together with student decides whether the corrected text is acceptable or not.

The student can decide to produce another version, to make a better text, but making the next version can also be suggested by teacher. The final version of the text "steps in" to the next stage, i.e. the one that is estimated to be the correct final text relating to content, style and composition ...

Check your spelling, correct errors. - Each segment of the text does not require revision, particularly in the first cycle (first, second and third grade), where the goal is to encourage students to write freely without constant burden of spelling rules, punctuation and sentence structure. At this stage, the spelling corrections are done and the full text is formatted. Since the best way to learn is through mistakes, you should not straightaway correct the student's mistakes, but help him to detect and correct them himself.

"Authors" should be allowed first to improve their own text and should be instructed to use a Dictionary or Spelling Grammar Guide or some other guide that will help them to correct mistakes. Younger students will not be able to finish this part of the work completely by themselves, so they must be helped by the teacher in producing the final version they want to publish.

Carefully rewrite or retype the text -Text that is ready for publication should be technically polished (same font, font size, paragraph, indented start of a new paragraph, highlighted units in the task), without spelling errors, and correct in language and content.

If you want - publish your article/book and present it to readers. - "Author/writer" needs to decide himself about how his book will look like. Younger students can be helped by teacher in preparation of the book. It is preferred to print the text from a computer. The cover page should have a title and the full name of the "author." "Writer" should be allowed to present 
his text to different types of audience. The fact that the work will be listened or read by others is an important motive both for writing and text processing.

The presentation of the book/article can be organized: in the class, during a literary day in activities, within the activities of school library, school summits, etc.

Assessing students' creations in this method approach is formative. The teacher monitors the work of each student and provides suggestions and guidance, assessing what was previously done. It also requires students to self assess their works and argue their opinions. The assessment includes a small group of peers. But, that's a whole area that needs special attention.

Implementation of methodological approach The Creator's path confirmed two important observations that teachers emphasized immediately after the first application:

This approach encourages all students (all students write)

It develops their independence in this field (parents do not participate in making the composition).

\section{Conclusions}

Conclusions on the implementation of method approach The Creator's path in the period November 2011 - August 2013:

Students understand and recognize that text creation is a process; that this process enables them to learn and improve their writing skills because it results in a quality task.

Working together on electing the theme and its detailed analysis, in which the theme point of view / focus issues and subject are specified, is the initial step that greatly motivates students and encourages for further work on their texts; when selecting and formulating the titles students need help, so that they can be clear about what to write and with that point of view, and particularly is so for primary school children; not necessary to insist on the very notions of subject and point of view, but on understanding them.

Data collection and their organization into titles that make up the plan of the task, with prior removal of everything that is not directly related to the theme or main idea of the text, encourages students and makes them safer in future work on text creation. While working on the text plan students improve many skills: careful observation and identification of details in the immediate environment, observation and identification of indirect character details, thinking ...; Also, it is practicing the important intellectual operations: hierarchical, chronological or causal arrangement of concepts and details; the majority of students accept making the text plan as an important and useful part of the text creation process.

Older students, especially the ninth grade, initially, in most schools, refused to develop a text plan because "so far we have not worked that way, and we know how and what about to write "; their works, however, showed that the majority of them needed some form of text plan, that after such an organization of materials the texts are much better and that it's a very important step in the process of text creation; when the introduction of the teaching process starts at a later age, application of the certain stages should vary; quality analysis of tasks will show whether a step in text creation was truly redundant or not, which also differs from student to student.

Consultation about the text contributes to the improvement of all its segments (composition, content, style and language, spelling...); so far, the consultation took place more frontally, but the Project insists on student-teacher and student-student consultations, as well as consultations within small groups of peers.

Development of an improved version of the text is an important step, but not easily accepted by younger students. However, from the third grade they recognize that this step provides an opportunity for success and most of them are glad to use it.

Students of all ages write more gladly and have a lot more confidence when this activity is in question.

The proposed method approach is necessary to apply with the first steps in learning and teaching to create the text.

The process was realized in the regular classes, then in additional and supplementary teaching, and within leisure activities; some segments were included in the part of class with similar aim; part of the activities the students were doing at home, but due to the fact that parents were aware of this process as a way of teaching the skill of writing and helping the students and that students understood that they themselves could improve their texts, teachers pointed out that it was obvious that the texts were without "parents touch". 
The circumstances of the school (e.g. written exercises and written assignments), national testing and life situations demand the texts to be produced in a short period of time, for example - in an hour. It was concluded, therefore, that the students through this process learn and practice to create text, that process itself motivates and builds confidence and allows students to gain a certain routine and be faster when they need to write the text in one hour (written exercises, written assignment) or within the limited time available for the exam: external-internal assessment, external assessment, external graduation exam ... So, by applying the proposed method, the student is also trained to create a quality text in a time-limited circumstances.

It is essential that the annual schedule of objectives and contents has at least one process planned in each semester.

Although the method itself is based on an individualized approach to teaching for culture of oral and written expression development, teachers haven't as yet fully recognized and implemented it; this needs to be improved.

The process of applying the proposed method with the students of the first cycle resulted in the improvement of oral and written expression; significant improvement is observed in verbal expression compared to previous generations: the willingness to speak out in front of class, richer vocabulary, a better sentence, the correlated expression of story content etc.

Colleagues of other professions recognized this process of text creation as an useful technique for writing articles within their subjects, so that they applied a similar procedure in their classes.

The conclusions resulting from the application of this teaching method show that it provides the enhancement of the knowledge and skills necessary to create texts of various types, thereby contributing to the development of functional literacy among students.

\section{References}

[1] Booth, D. \& Swartz, L. (2004): Literacy Techniques, Ontario, Canada: Pembroke Publishers Limited.

[2] Burke Walsh, K. (1996): Creating child-centered classrooms, 6-7 Year Olds, Step By Step: A Program for Children and Families. Children's Resources International, Inc., Washington, DC; Open Society Inst., New York, NY.

[3] Burke Walsh, K. (1997): Creating child-centered classrooms, 8-10 Year Olds, A Program for Children and Families Children's Resources International, Inc., Washington, DC; Open Society Inst., New York, NY.

[4] Grosman, M. (2010): U obranu čitanja, čitatelj i književnost u 21. Stoljeću, Zagreb: Facta.

[5] Dimitrijević, R. (1969): Osnovi teorije pismenosti, prerađeno i dopunjeno izdanje, Beograd: „Vuk Karadžić“

[6] Durković, N., Kovačević, I. i dr (2006): Studija: Republičko testiranje obrazovnih postignuća učenika/ca III razreda osnovne škole iz maternjeg jezika i matematike, Podgorica: Zavod za školstvo.

[7] European Commission (2011): Teaching Reading in Europe, Contexts, Policies and Practices, Brussels: EACEA P9 Eurydice.

[8] Jaćimović, Ž.: Prezentacija PISA 2009: Postignuća naših učenika u programu međunarodnog testiranja, sajt Ispitnog centra Crne Gore: http://www.iccg.co.me/

[9] Jovanović, V. (2011): Faktori napredovanja na testu čitalačke pismenosti, Psihološka istraživanja, Vol. XIV (2), 135-155.

[10] Campbell, R.J., Kelly, D.L., Mullis, I.V.S., Martin, M.O., Sainsbury, M. (2001): Framework and Specification for PIRLS Assessment 2001, Boston: Lynch School of Education, Boston College.

[11] Ilić, P. (1998): Srpski jezik i književnost u nastavnoj teoriji i praksi, Novi Sad: Zmaj.

[12] Kirsh, I., de Jong, J., Lafontaine, D., McQueen, J., Mendelovits, J., Monseur, C. (2002): Reading for Change: Performance and Engagement across Countries, Paris: OECD Publications.

[13] Kvaščev, R. (1974): Razvijanje stvaralačkih sposobnosti kod učenika, Beograd: Zavod za udžbenike i nastavna sredstva 
[14] Kvaščev, R. (1977): Kako razviti stvaralačke sposobnosti, Beograd: Zavod za udžbenike i nastavna sredstva

[15] Lešić, Z. (2008): Teorija književnosti, Beograd: „Službeni glasnik“

[16] Marinković, S. (2000): Metodika kreativne nastave srpskog jezika i književnosti, Beograd: Kreativni centar

[17] Nikolić, M. (2009): Metodika nastave srpskog jezika i književnosti, 5. dopunjeno izdanje, Beograd: Zavod za udžbenike

[18] Ministarstvo prosvjete i nauke (2008): Nacionalni izvještaj o postignućima učenika u okviru programa za međunarodno testiranje učenika - PISA 2006, Podgorica: Ministarstvo prosvjete i nauke, OECD, FOSI.

[19] Pavlović Babić, D., Baucal, A. (2010): Čitalačka pismenost kao mera kvaliteta obrazovanja: procena na osnovu PISA 2009 podataka, Psihološka istraživanja, Vol. XIII 2, 241-260.

[20] Rosandić, D. (2005): Metodika književnog odgoja, Zagreb: Školska knjiga.

[21] Stevanović, M. (1988): Teorija i praksa u nastavi umenog i pismenog izražavanja, Gornji Milanovac: Dečje novine

[22] Street, B. V. (1993a). (Ed.). Cross-cultural approaches to literacy. New York: Cambridge University Press.

[23] Street, B. V. (1993b). The new literacy studies: Guest editorial. Journal of Research in Reading, 16(2), 81-97.

[24] Havelka, N. i tim istraživača (2001): Istraživanje obrazovnih postignuća učenika osmog razreda iz pet osnovnih škola u Crnoj Gori, u: Sveobuhvatna analiza sistema osnovnog obrazovanja u SRJ, Beograd: UNICEF.

[25] Visinko, K. (2010): Jezično izražavane u nastavi hrvatskog jezika. Pisanje, Zagreb: Školska knjiga

[26] Zavod za školstvo, Ispitni centar Crne Gore (2013): PISA - Crna Gora, Preliminarni izvještaj, Podgorica: Zavod za školstvo, Ispitni centar Crne Gore

[27] Živković, D. (2001): Teorija književnosti sa teorijom pismenosti, Beograd: „Draganić“ 